\title{
RUPTURE OF THE INTERVENTRICULAR SEPTUM
}

\author{
BY \\ R. G. S. MALONE AND W. E. PARKES \\ From the Institute of Pathology, Queen's University, Belfast, The Royal Victoria \\ Hospital, Belfast, and the Belfast City Hospital \\ Received February 7, 1955
}

Rupture of the interventricular septum is an uncommon complication of cardiac infarction. The seven cases reported here illustrate the clinical and pathological features of this condition.

In 1948, Fowler and Failey, in a survey of previously reported cases, found records of 60 patients who had myocardial infarction involving the interventricular septum with subsequent septal rupture ; in 17 of these the condition was recognized clinically. Physicians are now becoming increasingly aware of this complication of cardiac infarction and in recent years a number of isolated case reports have appeared (Leonard and Daniels, 1938; Nareff et al., 1950; Black, 1952; Evans and Anderson, 1952; Hamilton et al., 1954; Arons and O'Rourke, 1954.)

The following seven instances of septal rupture occurred in patients admitted to the Royal Victoria Hospital, Belfast, and to the Belfast City Hospital. In the case of patients not seen personally by one of us, clinical and pathological records were made available by the physicians and pathologists concerned. The clinical and pathological features of all seven cases are summarized in tabular form, and those of one case are presented in some detail.

TABLE I

The Clinical Features of Seven Cases of Ruptured Interventricular Septum

\begin{tabular}{|c|c|c|c|c|c|c|c|c|c|}
\hline & Age & $\begin{array}{c}\text { Blood } \\
\text { pressure } \\
(\mathrm{m} . \mathrm{m} / \mathrm{Hg}) .\end{array}$ & Auscultation & Thrill & $\begin{array}{l}\text { Cardiac } \\
\text { rhythm }\end{array}$ & Pallor & $\underset{(\mathrm{g} . \% .)}{\mathrm{Hb}}$ & Cyanosis & $\begin{array}{l}\text { Peripheral } \\
\text { œdema }\end{array}$ \\
\hline Case 1 & 56 & $115 / 105$ & $\begin{array}{l}\text { Loud systolic } \\
\text { murmur maximal } \\
\text { in fourth left } \\
\text { intercostal space }\end{array}$ & Present & Regular & ++ & $14 \cdot 1$ & ++ & \\
\hline Case 2 & 75 & $190 / 130$ & $\begin{array}{l}\text { Systolic murmur } \\
\text { heard over } \\
\text { præcordium }\end{array}$ & & Regular & & & ++ & Absent \\
\hline Case 3 & 74 & $90 / ?$ & $\begin{array}{l}\text { Loud systolic } \\
\text { murmur all over } \\
\text { præcordium }\end{array}$ & & $\begin{array}{l}\text { Fibrillation } \\
150 / \mathrm{min} .\end{array}$ & ++ & $12 \cdot 7$ & & \\
\hline Case 4 & 50 & $130 / 100$ & $\begin{array}{l}\text { Harsh systolic and } \\
\text { diastolic murmurs } \\
\text { between apex beat } \\
\text { and sternum }\end{array}$ & & & ++ & $11 \cdot 2$ & ++ & \\
\hline Case 5 & 75 & $120 / 80$ & $\begin{array}{l}\text { Heart sounds } \\
\text { faint and almost } \\
\text { inaudible }\end{array}$ & & $\begin{array}{l}\text { Gallop } \\
\text { rhythm }\end{array}$ & ++ & & ++ & Gross \\
\hline Case 6 & 87 & $130 / 80$ & $\begin{array}{l}\text { Loud blowing } \\
\text { systolic murmur } \\
\text { maximal to left } \\
\text { of sternum }\end{array}$ & Present & & ++ & $6 \cdot 4$ & & \\
\hline Case 7 & 74 & $135 / 90$ & $\begin{array}{l}\text { Mitral systolic and } \\
\text { diastolic murmurs }\end{array}$ & & & ++ & & & Gross \\
\hline
\end{tabular}


TABLE II

The Post-mortem Findings in Seven Cases of Ruptured Interventricular Septum

\begin{tabular}{|c|c|c|c|c|c|c|c|}
\hline & $\begin{array}{c}\text { Heart } \\
\text { weight } \\
\text { (g.) }\end{array}$ & Occlusion & $\underset{\text { infarcted }}{\text { Area }}$ & $\begin{array}{l}\text { Site of } \\
\text { rupture }\end{array}$ & $\begin{array}{c}\text { Edema } \\
\text { lungs }\end{array}$ & $\begin{array}{l}\text { Liver } \\
\text { weight } \\
\text { (g.) }\end{array}$ & $\begin{array}{c}\text { Central } \\
\text { zonal } \\
\text { necrosis }\end{array}$ \\
\hline $\begin{array}{l}\text { Case 1 } \\
\text { (male) }\end{array}$ & 550 & $\begin{array}{l}\text { Anterior descending } \\
\text { branch left } \\
\text { coronary artery }\end{array}$ & $\begin{array}{l}\text { Antero-septal } \\
\text { region }\end{array}$ & $\begin{array}{l}\text { Below } \\
\text { centre of } \\
\text { anterior } \\
\text { septal } \\
\text { margin }\end{array}$ & $\begin{array}{c}\text { Acute } \\
\text { cedema } \\
\text { present }\end{array}$ & 1600 & Present \\
\hline $\begin{array}{l}\text { Case } 2 \\
\text { (male) }\end{array}$ & 500 & $\begin{array}{l}\text { Anterior descending } \\
\text { branch left } \\
\text { coronary artery }\end{array}$ & $\begin{array}{l}\text { Septum extending } \\
\text { to posterior wall } \\
\text { left ventricle }\end{array}$ & $\begin{array}{l}\text { Posterior } \\
\text { apical } \\
\text { part of } \\
\text { septum }\end{array}$ & $\begin{array}{c}\text { Moderate } \\
\text { odema }\end{array}$ & 1600 & Present \\
\hline $\begin{array}{c}\text { Case } 3 \\
\text { (female) }\end{array}$ & 560 & $\begin{array}{l}\text { No satisfactory } \\
\text { occlusion found. } \\
\text { Gross atheroma } \\
\text { present }\end{array}$ & $\begin{array}{l}\text { Antero-septal } \\
\text { region }\end{array}$ & $\begin{array}{l}\text { Lower } \\
\text { apical } \\
\text { part of } \\
\text { septum }\end{array}$ & $\begin{array}{l}\text { Chronic } \\
\text { venous } \\
\text { conges- } \\
\text { tion }\end{array}$ & 1500 & Present \\
\hline $\begin{array}{l}\text { Case } 4 \\
\text { (male) }\end{array}$ & 500 & $\begin{array}{l}\text { Anterior descending } \\
\text { branch left } \\
\text { coronary artery }\end{array}$ & $\begin{array}{l}\text { Antero-septal } \\
\text { region }\end{array}$ & $\begin{array}{l}\text { Lower } \\
\text { apical } \\
\text { part of } \\
\text { septum }\end{array}$ & $\begin{array}{c}\text { Gross } \\
\text { œdema }\end{array}$ & 2400 & Present \\
\hline $\begin{array}{c}\text { Case } 5 \\
\text { (female) }\end{array}$ & 480 & $\begin{array}{l}\text { Anterior descending } \\
\text { branch left } \\
\text { coronary artery }\end{array}$ & $\begin{array}{l}\text { Antero-septal } \\
\text { region }\end{array}$ & $\begin{array}{l}\text { Lower } \\
\text { apical } \\
\text { part of } \\
\text { septum }\end{array}$ & $\begin{array}{l}\text { Acute } \\
\text { oedema }\end{array}$ & 1400 & Present \\
\hline $\begin{array}{l}\text { Case } 6 \\
\text { (male) }\end{array}$ & 400 & $\begin{array}{l}\text { Atheroma and } \\
\text { calcification left } \\
\text { coronary. Right } \\
\text { coronary abnor- } \\
\text { mally small }\end{array}$ & $\begin{array}{l}\text { Lower half of } \\
\text { septum }\end{array}$ & $\begin{array}{l}\text { One inch } \\
\text { above } \\
\text { apex in } \\
\text { septum }\end{array}$ & $\begin{array}{l}\text { Edema } \\
\text { with } \\
\text { terminal } \\
\text { pneu- } \\
\text { monia }\end{array}$ & 900 & $\begin{array}{l}\text { Central } \\
\text { zonal } \\
\text { conges- } \\
\text { tion }\end{array}$ \\
\hline $\begin{array}{c}\text { Case } 7 \\
\text { (female) }\end{array}$ & 350 & $\begin{array}{l}\text { Gross atheroma. } \\
\text { Hæmorrhage into } \\
\text { plaque in left } \\
\text { anterior descending } \\
\text { coronary }\end{array}$ & $\begin{array}{l}\text { Anterior wall left } \\
\text { ventricle and } \\
\text { apical portion of } \\
\text { septum }\end{array}$ & $\begin{array}{l}\text { Apical } \\
\text { part of } \\
\text { septum }\end{array}$ & $\begin{array}{l}\text { Acute } \\
\text { oedema }\end{array}$ & 1600 & $\begin{array}{l}\text { Central } \\
\text { zonal } \\
\text { conges- } \\
\text { tion }\end{array}$ \\
\hline
\end{tabular}

\section{CASE REPORT}

G. McK., a 56-year-old man, was admitted to hospital with a diagnosis of internal hæmorrhage. On examination he was seen to be shocked and cyanosed. His conjunctivæ were blanched to such an extent as to suggest profound anæmia. The hæmoglobin was 99 per cent $(14.1 \mathrm{~g} . / 100 \mathrm{ml}$.). The cardiac rhythm was regular, the pulse volume poor, and there was gross jugular venous congestion. The blood pressure was not recordable. A loud systolic murmur was maximal in the fourth left intercostal space just to the left of the sternum. Pulmonary œdema was present and the liver was considerably enlarged. There were 15,000 leucocytes/cu. mm. A chest X-ray showed moderate cardiac enlargement and pulmonary congestion. An electrocardiogram showed a typical antero-septal left ventricular infarct (Fig. 1). The blood urea was $147 \mathrm{mg}$. per $100 \mathrm{ml}$. Four days later, the patient became disorientated and increasingly cyanosed, and icterus was noted. A further electrocardiogram revealed no extension of the infarction. He lapsed into coma and his condition deteriorated further. Three days later he died. The records of this patient revealed that he had been treated for hypertension several years previously at which time his blood pressure was 240/140 and an electrocardiogram showed only hypertensive changes. His heart sounds at that time were normal.

Post-mortem Findings. The body was icteric. There was a fibrinous pericarditis with an adhesion on the anterior surface of the left ventricle (Fig. 2). The heart weighed $550 \mathrm{~g}$. There was ante-mortem 
thrombus in the appendage of the dilated right atrium. The right ventricle had an opening in the anterosuperior part of the septal wall, with surrounding discoloured and hæmorrhagic myocardium. The left atrium was normal. The left ventricle was dilated, especially in the septal region where the dilatation was aneurysmal. It was here that perforation had occurred. The apical third of the septum, the anterior wall of the left ventricle and a small portion of the posterior wall at the apex were discoloured and thin. Apical

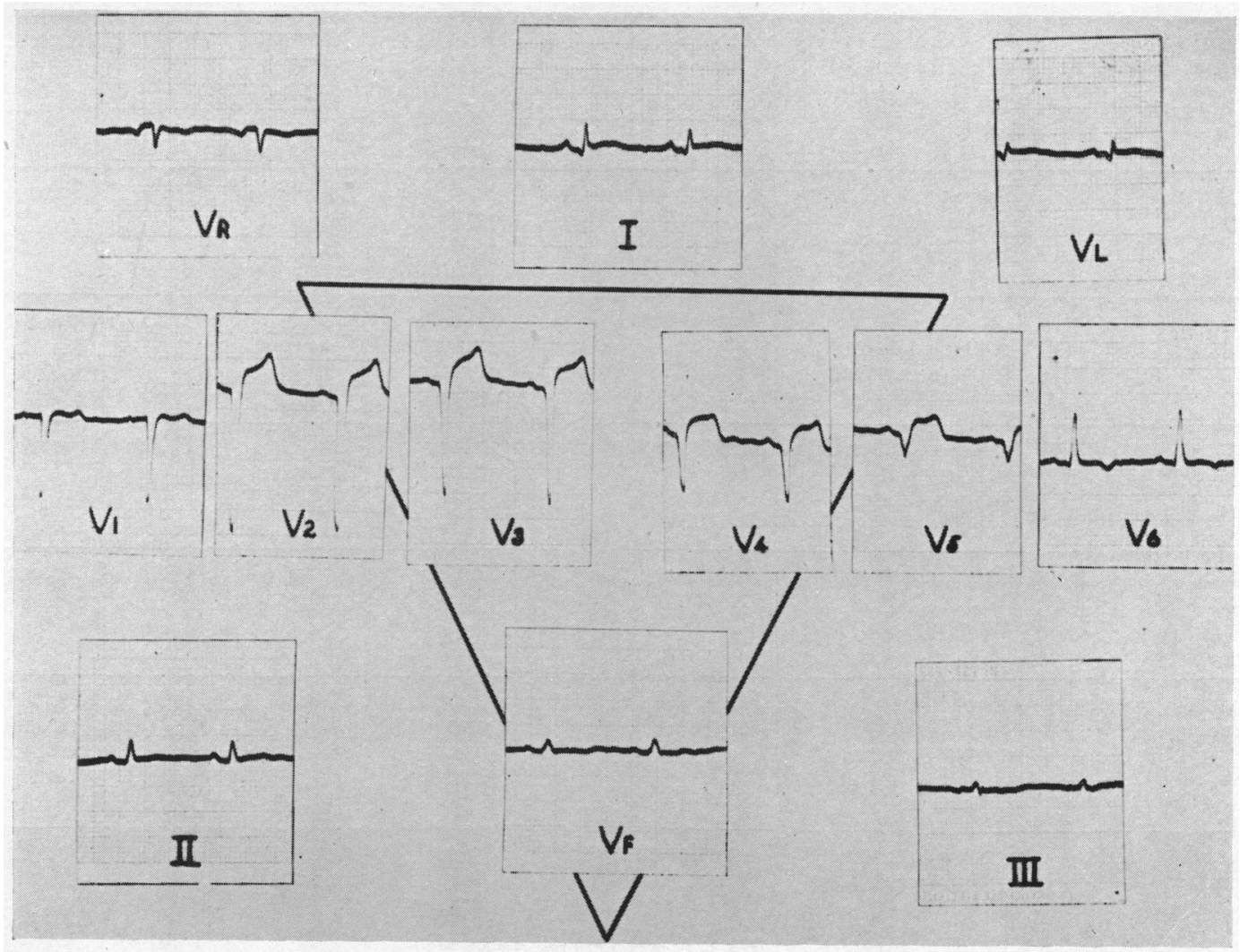

FIG. 1.-Electrocardiogram showing typical features of antero-septal infarction of the left ventricle.

endocardial thrombi were present. The anterior descending branch of the left coronary artery contained a thrombotic occlusion near its origin.

Histologically the infarcted areas showed extensive necrosis of the myocardium. In some parts the entire thickness of the ventricle was involved with the exception of a narrow surviving epicardial zone. The coronaries were markedly atheromatous and the presence of a recent thrombotic occlusion was confirmed. There was acute pulmonary œdema, macroscopically and histologically.

The liver weighed $1600 \mathrm{~g}$. and had a " nutmeg " pattern. Histologically the liver showed intense central zonal congestion and necrosis (Fig. 3).

\section{Discussion}

Sager (1934) found that only 3 per cent of myocardial ruptures occurred through the interventricular septum. This infrequency of septal rupture has been ascribed by Gross (1921) to its rich anastomotic blood supply. Most authors agree that septal rupture is found in the presence of severe coronary arteriosclerosis. However, an assessment of this problem must include consideration of other factors. The splinting effect of the right ventricular pressure in reducing the pressure gradient across the septum tends to reduce the incidence of interventricular septal rupture. 


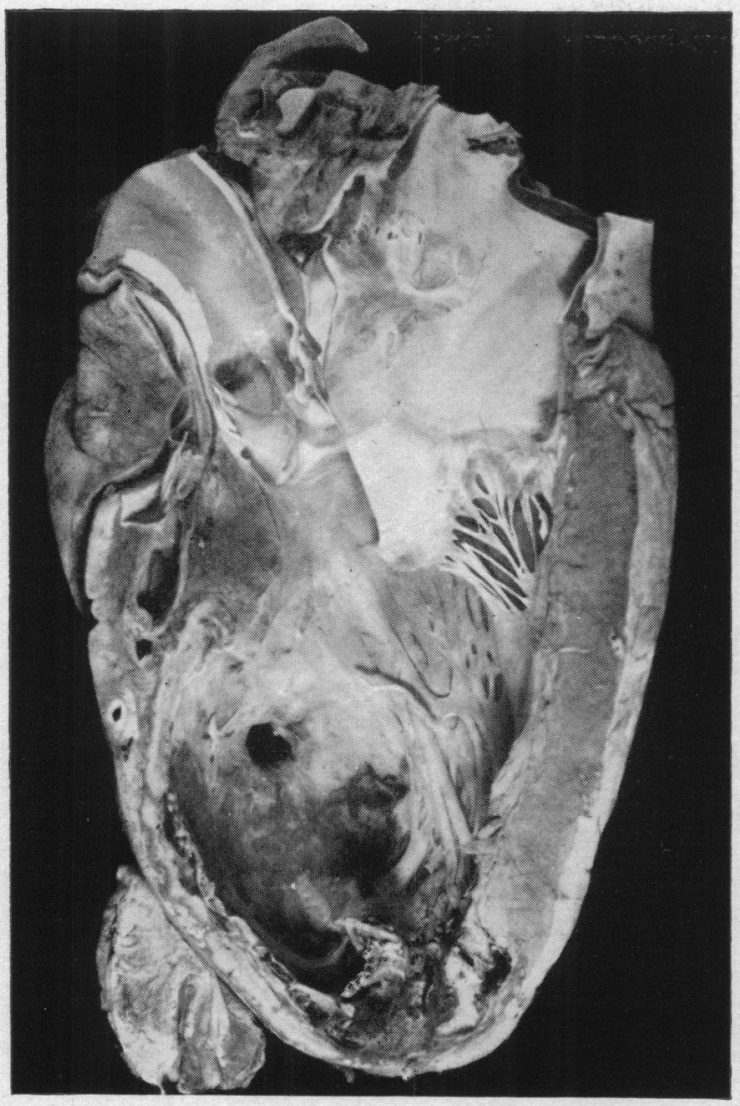

FIG. 2.-Left heart showing the infarcted area, septal perforation, pericardial adhesions and mural thrombus.

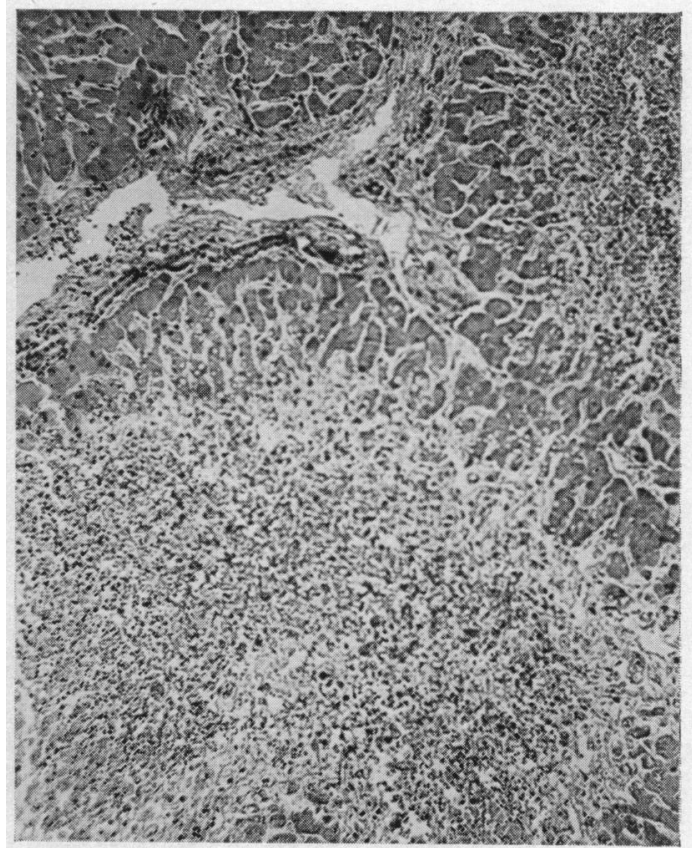

FIG. 3.-Microscopical appearances of liver showing central zonal necrosis $(\times 100, H . \&$ E. $)$

On the other hand, if hypertension persists after the occurrence of septal or non-septal infarction, ventricular rupture is more likely to result (Edmondson and Hoxie, 1942).

The following factors appear to contribute to this complication of cardiac infarction.

(1) Complete or almost complete infarction of the full thickness of the septal muscle.

(2) The time factor. Most septal ruptures occur between the third and twelfth days after infarction. Edmondson and Hoxie (1942) found the average survival period to be $7 \cdot 4$ days.

(3) Age. The average age of the patients in this series was 70 years.

(4) Hypertension. This is difficult to assess clinically because many of these patients are admitted for the first time after the occurrence of infarction with a consequent fall in blood pressure. The heart weight provides an index of the degree of cardiac hypertrophy present at death. In this series the average heart weight was above $475 \mathrm{~g}$.

The pathological effects of septal rupture are of considerable interest. Intense vascular congestion of the liver lobules occurs and in five of our cases it was associated with central zonal necrosis of the liver lobules (Fig. 3). In our first case the degree of liver damage was such as to result in obvious jaundice. The septal rupture is usually small. Sager (1934) commented on the fact that the præcordial murmur is often loud, despite the patient's poor general condition and that it is usually maximal to the left of the lower end of the sternum.

Nareff et al. (1950) stated that it might be confused with that of aortic stenosis, mitral insufficiency, or rupture of chordæ tendineæ or papillary muscles. Fowler and Failey (1948), discussing 
rupture of a papillary muscle, state that this complication is to be suspected when the condition of the patient suddenly becomes worse, the murmurs become louder and nearer the apex, and the ensuing heart failure is left-sided rather than right-sided. They considered that rupture of chordæ tendineæ was more likely in middle-aged or elderly patients who, suddenly, without dramatic incident, develop a loud systolic murmur, usually with a thrill, maximal at the cardiac apex and along the left sternal border. Congestive heart failure in these cases does not usually develop for months or years.

Rupture usually occurs in the apical end of the septum near one or other wall of the ventricle. This was held by Nareff et al. (1950) to account for the rarity of intraventricular conduction defects. They mention that rupture is often associated with a dramatic deterioration in the patient's general condition with peripheral circulatory failure and the rather abrupt appearance of signs of right ventricular failure. In our experience, the shock and peripheral circulatory failure following septal rupture have been so marked as to lead to an erroneous clinical impression of anæmia on several occasions.

It would appear that septal rupture is more likely to occur in the elderly hypertensive patient with advanced coronary arteriosclerosis, who has suffered cardiac infarction during the previous fortnight. The prognosis seems to be uniformly poor. All the patients in this series died within a few weeks of septal rupture.

\section{SUMMARY}

The clinical and pathological findings in seven patients who had cardiac infarction involving the interventricular septum with consequent septal rupture are presented.

The causation and clinical features of this unusual complication of cardiac infarction are discussed. Suggestive clinical signs are the appearance of a loud præcordial systolic murmur, maximal to the left of the sternum in the fourth intercostal space, and often an associated systolic thrill in this area. At the time of septal rupture the patient's condition deteriorates conspicuously; there is usually profound shock, with peripheral circulatory failure and right heart failure.

We are indebted to Professor Biggart and Professor Bull for their ready advice during the preparation of this paper. We wish to thank Professor Biggart, Dr. Robert Marshall, Dr. T. H. Crozier, Dr. T. A. Kean and Dr. George Adams for permission to publish details of these patients, and Mr. David Mehaffey, A.R.P.S., for the photography.

\section{REFERENCES}

Arons, J. J., and O'Rourke, P. (1954). J. Amer. med. Ass., 155, 1050.

Black, A. B. (1952). Brit. Heart J., 14, 288.

Edmondson, H. A., and Hoxie, H. J. (1942). Amer. Heart J., 24, 719.

Evans, B., and Anderson, W. F. (1952). Brit. Heart J., 14, 537.

Fowler, N. O., and Failey, R. B., jr. (1948). Amer. J. med. Sci., 215, 534.

Gross, L. (1921). The Blood Supply of the Heart. New York, P. B. Hoeber, Inc.

Hamilton, G., Jones, I., and Stuart, A. G. (1954). Brit. Heart J., 16, 463.

Leonard, B. W., and Daniels, W. B. (1938). Amer. Heart J., 16, 751.

Nareff, M. J., Sklar, L. J., Kelly, F. T., and Reuling, J. R. (1950). New Engl. J. Med., 243, 431.

Sager, R. V. (1934). Arch. intern. Med., 53, 140. 